\title{
Impact of flaxseed intake upon metabolic syndrome indicators in female Wistar rats ${ }^{1}$
}

\author{
Impacto do consumo da linhaça sobre os indicadores da \\ síndrome metabólica em ratos fêmeas Wistar
}

\section{Lívia Hipólito Cardozo Brant", Ludmila Ferreira Medeiros de França Cardozo", Luís Guillermo Coca Velarde ${ }^{\mathrm{III}}$, Gilson Teles Boaventura $^{\mathrm{IV}}$}

${ }^{\mathrm{I}}$ Master, Nutricionist, Department of Nutrition and Dietetic, UFF, Niteroi-RJ, Brazil. Responsible for intellectual and scientific content of the study, manuscript writing.

acquisition and interpretation of data.

IIPhD, Nutricionist, Department of Nutrition and Dietetic, UFF, Niteroi-RJ, Brazil. Acquisition of data, helped with technical procedures and critical revision.

IIIPhD, Associate Professor, Department of Statistics, UFF, Niteroi-RJ, Brazil. Responsible for statistical analysis.

${ }^{\mathrm{IV}} \mathrm{PhD}$, Associate Professor, Department of Nutrition and Dietetic, UFF, Niteroi-RJ, Brazil. Supervised all phases of the study and critical revision.

\begin{abstract}
PURPOSE: To evaluate whether the prolonged consumption of flaxseed minimize the factors that trigger MS in healthy rats.

METHODS: Pregnant rats were divided immediately after delivery into two groups during the lactation period, a control group (CG) receiving casein-based diet with $17 \%$ of protein, and a Flaxseed group (FG) with casein-based diet plus $25 \%$ of flaxseed. At weaning, 12 offspring of each group continued to receive the same feed but with $10 \%$ of protein up to 200 days old.

RESULTS: FG showed a significant reduction in body weight $(\mathrm{p}=0.001)$, total cholesterol levels $(\mathrm{p}<0.0001)$, triglycerides $(\mathrm{p}=0.0001)$, and glucose $(\mathrm{p}=0.001)$.

CONCLUSION: The flaxseed alters the indicators related to development of metabolic syndrome, because it has beneficial effects on lipids and glucose profiles and prevents the excess of body weight gain.
\end{abstract}

Key words: Flax. Triglycerides. Metabolism. Glucose. Rats.

\section{RESUMO}

OBJETIVO: Avaliar se o consumo prolongado de linhaça pode minimizar os fatores que desencadeiam síndrome metabólica em ratos fêmeas saudáveis.

MÉTODOS: Ratos fêmeas grávidas foram distribuidas após o parto em dois grupos durante o período de lactação: grupo controle (GC) recebendo dieta à base de caseína com $17 \%$ de proteína, e um grupo Linhaça (GL), com dieta à base de caseína adicionada de $25 \%$ de semente de linhaça. Ao desmame, 12 filhotes de cada grupo continuaram a receber as rações citadas acima, porém com 10\% de proteína, até os 200 dias de vida.

RESULTADOS: O GL mostrou uma redução significativa do peso corporal ( $\mathrm{p}=0,001)$, no colesterol total ( $\mathrm{p}<0,0001)$, triglicerídeos $(\mathrm{p}=0,0001)$ e na glicemia $(\mathrm{p}=0,001)$.

CONCLUSÃO: A linhaça altera os indicadores relacionados ao desenvolvimento da síndrome metabólica por ter efeitos benéficos no perfil lipídico e glicêmico, e previne o excesso de ganho de peso corporal.

Descritores: Linho. Triglicerídeos. Metabolismo. Glucose. Ratos. 


\section{Introduction}

Metabolic syndrome (MS) is the most common disease today, representing one of the major public health problems of the century, and its incidence has gradually increased over time ${ }^{1,2}$. Its prevalence varies worldwide, because it is directly related to aging, ethnicity of the studied populations, and criteria for its diagnosis. It is estimated that one quarter of the world population has $\mathrm{MS}^{3,4}$. This metabolic alteration consists of a simultaneous presence of a set of cardiovascular risk factors ${ }^{5}$ characterized by hypertension, abdominal obesity, increased triglycerides, decreased high density lipoproteins (HDL-c), and increased glycemia/type 2 diabetes ${ }^{6-1}$.

Preventive measures and therapeutic strategies, such as changes in lifestyle including nutrition interventions and physical activity, are the possible ways to avoid the onset of $\mathrm{MS}^{6}$.

Flax plant is the most abundant source of omega-3 $(\alpha$-linolenic acid, ALA) and can be easily found, as well as being cheaper than the fish oil, which is also the source of this fatty $\operatorname{acid}^{7}$. ALA is an essential polyunsaturated fatty acid dependent on foods ingestion that contain it, since it cannot be synthesized by the human body.

From $41 \%$ of the total fat present in flaxseed oil, $57 \%$ come from the omega 3, which has anti-inflammatory, antithrombotic, and antiarrhythmic properties ${ }^{8}$.

Based on the results of clinical trials, epidemiological investigations, and experimental studies, it has been suggested that ALA intake has a high impact on cardiovascular disease (CVD), which, in turn, led to an increased consumption of polyunsaturated fatty acid. For this reason, the use of flaxseed has been advocated in the prevention of heart disease and therefore the MS, which is currently the most common metabolic disease among these patients $^{9}$.

Flaxseed also contains other components with beneficial effects on the organism, such as dietary fiber and lignans, from which the Secoisolariciresinol diglucoside (SDG) is the main ${ }^{10}$. This oilseed is considered a functional food, producing metabolic and physiological health benefits, in addition to its nutritional properties. Its consumption has been increasing progressively because it is a popular alternative to pharmacological treatment ${ }^{11}$ Many studies have shown its positive effects when used as a supplemental feeding. These effects are manifested as improvement in lipid profile ${ }^{12}$, reducing the development of type 1 and type 2 diabetes mellitus ${ }^{13}$, reducing blood pressure ${ }^{14}$, and controlling weight gain ${ }^{15}$.

Taking into account the mentioned researches, the hypothesis of this work is that prolonged consumption of flaxseed minimizes the factors that trigger the MS, leading to individual improvement of indicators that comprise it. This study aims to evaluate the effects of flaxseed in body weight gain, blood glucose levels, and lipid profile in healthy Wistar female rats that consumed flaxseed since the lactation period until mature age.

\section{Methods}

This research project was approved by Ethics Committee on Animal Research of Fluminense Federal University (UFF), Niteroi-RJ, Brazil, under n. 00104-09. All procedures are in accordance with the provisions of Brazilian Society of Science and Laboratory's Animals- SBCAL.

The biological assay was carried out in 12 pregnant Wistar female rats from the colony of Laboratory of Experimental Nutrition (LabNE), Fluminense Federal University, Niterói, RJ, Brazil. All them were nulliparous, 90 days old, mated at a ratio of 3 females per male, receiving commercial feed (23\% of protein, Nuvilab $^{\circledR}$, Nuvital Ltda., Parana State, Brazil).

After delivery, mothers rats were randomly divided into 2 groups $(n=6)$, receiving throughout the lactation period the following diets: "For the control group (CG), a diet based exclusively on casein with $17 \%$ of protein, and for the flaxseed group (FG), a casein-based diet plus $25 \%$ of flaxseed with $17 \%$ of protein".

On completion of 21 days old, 12 offspring from each experimental group, chosen at random, continued to receive the mentioned diets, but with a lower protein concentration $(10 \%)$ until adulthood and euthanized at 200 days old. For this procedure, female rats were subjected to a short fast for six hours and anesthetized with Thiopentax ${ }^{\circledR}$ (Thiopental sodium 1g, Cristalia Chemicals Pharmaceuticals LTDA, Brazil), at $0.15 \mathrm{ml} / 100 \mathrm{~g}$ dose by body weight. Then, blood samples were collected by cardiac puncture for determination of biochemical concentrations. The retroperitoneal, mesenteric, and genital fat were removed and weighed on an analytical balance (Bosch S2000).

During the experiment, the animals were kept in polypropylene cages at $22^{\circ} \mathrm{C}$ room temperature and controlled periods of light/dark (12/12 hours), receiving water and food ad libitum. The weight and feed consumption were monitored three times per week until the end of the experiment.

\section{Experimental diets}

The flaxseeds were weighed and crushed in a blender to obtain the flour that was weighed, packed, stored in refrigerator, 
and used immediately for the diet preparation. The diets based on casein and flaxseed were prepared manually in LabNE. They were isocaloric and a mixture of vitamins and minerals was added to them, according to the standards of the Commitee on Laboratory Animal Diets (1979), modified according to the recommendations of the American Institute of Nutrition (16), with $17 \%$ of protein during lactation (AIN-93G) and 10\% after weaning (AIN-93M).

The diet offered to the flaxseed group had a concentration of $25 \%$ of flaxseed, in order to meet all the recommended fiber. The ingredients of the experimental diets were weighed and homogenized in industrial Hobart ${ }^{\circledR}$ mixer (Sao Paulo-SP, Brazil) with boiling water for starch gelatinization. The obtained mass was processed into pellets and dried in a ventilated oven (Fabbe$\operatorname{Primar}^{\circledR}$ n. 171, Sao Paulo-SP, Brazil) at $60^{\circ} \mathrm{C}$ for 24 hours and, after identification, it was stored under refrigeration until use. A diet based on flaxseed did not receive oil nor cellulose in its prepare, because this seed is extremely rich in fiber and lipids (Table 1).

TABLE 1 - Composition of $100 \mathrm{~g}$ of each experimental diet given during lactation (17\% of protein: AIN-93G) and after the lactation period ( $10 \%$ of protein: AIN-93M).

\begin{tabular}{ccccc}
\hline Ingredients & $\begin{array}{c}\text { Control } \\
\mathbf{1 7 \%}\end{array}$ & $\begin{array}{c}\text { Flaxseed } \\
\mathbf{1 7 \%}\end{array}$ & $\begin{array}{c}\text { Control } \\
\mathbf{1 0} \%\end{array}$ & $\begin{array}{c}\text { Flaxseed } \\
\mathbf{1 0} \%\end{array}$ \\
\hline Casein & 20.0 & 14.11 & 11.8 & 5.9 \\
Flaxseed & 0 & 25 & 0 & 25 \\
Cornstarch & 52.95 & 45.84 & 61.2 & 54.1 \\
Sucrose & 10 & 10 & 10 & 10 \\
Mineral Mix & 3.5 & 3.5 & 3.5 & 3.5 \\
Vitamin Mix & 1 & 1 & 1 & 1 \\
Soybean oil & 7 & 0 & 7 & 0 \\
Cellulose power & 5 & 0 & 5 & 0 \\
Choline bitartrate & 0.3 & 0.3 & 0.3 & 0.3 \\
L-cystina & 0.3 & 0.3 & 0.3 & 0.3 \\
BTHQ & 0.0014 & 0.0014 & 0.008 & 0.008 \\
Total & 100 & 100 & 100 & 100 \\
\hline
\end{tabular}

BTHQ: tert- butylhydroquinonel. According to AIN-93G and AIN-93M ${ }^{16}$.

\section{Biological analyzes}

Protein Efficiency Ratio (PER) is the method used to assess the quality of the ingested biological protein. It consists of the ratio between the animals' weight gain and protein consumption from zero to 28 days old. It is suitable for measuring the body mass variation as a reflection of global activity of ingested protein ${ }^{17}$.

Growth Index (GI) is calculated by the same formula of PER, but used after 28 days old ${ }^{15}$.

Food Efficiency Ratio (FER) is determined by the ratio between animals' weight variation and dietary intake during 28 days after weaning and reveals the extent that one gram of diet promotes increased body weight ${ }^{17}$.

Animals' weight is used to assess the variation of animals' body mass, which were weighed three times a week on Gehara ${ }^{\circledR}$ digital scale, with a maximum capacity of $3 \mathrm{~kg}$ and precision of $0.05 \mathrm{~g}$. The animals were weighed individually, suspended by the distal third of the tail and placed in polypropylene container.

Accumulated dietary intake: "To determine the animals' food profile, the offered ration was weighed on Gehara ${ }^{\circledR}$ digital scale every other day, so to check the ingested amount by each animal". The offer and feed leftover were recorded.

\section{Biochemical analyzes}

Ten millimeters of blood was collected via needles and vacuum tubes (VACUEETE), centrifuged during 15 minutes at $3500 \mathrm{rpm}$ to obtain serum; the sample was deposited in eppendorfs and stored in a freezer at $-20^{\circ} \mathrm{C}$ for analyzes.

These analyzes consisted of determining the total cholesterol concentration (TC), triglycerides (TG), and HDLusing commercial kits (BIOCLIN, Indústria Quibasa-química LTDA, Belo Horizonte-MG, Brazil), based on enzymatic and colorimetric methods. Glycemia was measured at the slaughter time with an automatic measuring device (ACCU CHECK-active, Roche $^{\circledR}$ ) based on the glucose oxidase reaction.

\section{Statistical analysis}

Data were presented as mean and standard deviation. Statistical analysis was performed with S-Plus software for Windows 6.0 and $\mathrm{p}$ values less than 0.05 were considered significant. Kolmogorov-Smirnov test was used to determine if the data had normal distribution. Student's t test was applied for data with normal distribution and Wilcoxon rank-sum test for the others (Mann Whitney).

\section{Results}

It was found that both groups had similar values for PER $(p=0.2667)$, CEA $(p=0.0829)$, and GI $(p=0.958)$. Dietary intake $(p=0.032)$ and protein intake $(p=0.032)$ during the 200 days of 
the experiment were significantly lower in the group treated with flaxseed (FG) than in the control group. There was no difference among initial weights of offspring in the experimental groups $(\mathrm{p}=0.422)$. However, at the assay end, animals supplemented with flaxseed had lower weight gain than the ones from CG $(p=0.001)$ (Table 2).

TABLE 2 - Data from biological analysis of offspring and of the experimental diets.

\begin{tabular}{cccc}
\hline Groups & $\begin{array}{c}\text { CG } \\
(\mathbf{n}=\mathbf{1 2})\end{array}$ & $\begin{array}{c}\text { FG } \\
(\mathbf{n}=\mathbf{1 2})\end{array}$ & $\mathbf{p}$ Value \\
\hline Protein Efficiency Ratio & $3.56 \pm 0.33$ & $3.37 \pm 0.19$ & $\mathrm{p}=0.2667$ \\
Food Efficiency Coeficient & $0.35 \pm 0.03$ & $0.32 \pm 0.01$ & $\mathrm{p}=0.0829$ \\
Growth rate & $1.39 \pm 0.12$ & $1.39 \pm 0.13$ & $\mathrm{p}=0.958$ \\
& $2536.61 \pm$ & $2249.65 \pm$ & $\mathrm{p}=0.032$ \\
Cumulative food intake (g) & 189.97 & 235.44 & \\
Cumulative food intake of & $253.66 \pm$ & $229.01 \pm$ & $\mathrm{p}=0.032$ \\
protein (g) & 18.99 & 23.54 & \\
Individual initial weight (g) & $6.3 \pm 0.37$ & $6.18 \pm 0.22$ & $\mathrm{p}=0.422$ \\
& $352.91 \pm$ & $317.2 \pm$ & $\mathrm{p}=0.001$ \\
\hline Final body weight (g)) & 24.03 & 9.33 & \\
\hline
\end{tabular}

$\mathrm{CG}=$ control group; $\mathrm{FG}=$ flaxseed group; $\mathrm{VFM}=$ visceral fat mass. The results are shown as mean and standard deviation. Significance was set at $\mathrm{p}<0.05$ level.

Analyzing the biochemical parameters, the values of total cholesterol $(p<0.001)$ and triglycerides $(p=0.0001)$ in FG are lower than in CG. The group supplemented with flaxseed showed higher numerical value in HDL- ${ }_{\mathrm{C}}$ levels, but no significant differences in relation to non-supplemented group. There was a better glycemic profile in FG ( $\mathrm{p}=0.001)$. The visceral fat mass (VFM) was not significantly different between groups; a reduction of $16 \%$ was noted, however, in the group treated with flaxseed (FG) (Table 3).
TABLE 3 - Data collected from offspring at 200 days old.

\begin{tabular}{cccc}
\hline Group & CG $(\mathbf{n}=\mathbf{1 2})$ & FG $(\mathbf{n}=\mathbf{1 2})$ & $\mathbf{p}$ Value \\
\hline Total Cholesterol & $21.15 \pm$ & $47.92 \pm$ & $\mathrm{p}<0.0001$ \\
$\mathbf{( m g / d l )}$ & 11.68 & 3.87 & \\
Triglycerides & $74.54 \pm$ & $150.91 \pm$ & $\mathrm{p}=0.0001$ \\
$\mathbf{( m g / d l )}$ & 19.75 & 35.47 & \\
HDL-c & $123.32 \pm$ & $108.20 \pm$ & $\mathrm{p}=0.15$ \\
$\mathbf{( m g / d l )}$ & 23.45 & 15.48 & \\
Glycemia & $102.25 \pm$ & $122 \pm$ & $\mathrm{p}=0.001$ \\
$\mathbf{( m g / d l )}$ & 10.86 & 8.12 & \\
$\mathbf{V F M}$ & $23.23 \pm$ & $27.65 \pm$ & $\mathrm{p}=0.3$ \\
$\mathbf{( g )}$ & 7.88 & 9.95 & \\
\hline
\end{tabular}

$\mathrm{CG}=$ control group $; \mathrm{FG}=$ flaxseed group $; \mathrm{VFM}=$ visceral fat mass. The results are shown as mean and standard deviation. Significance was set at $\mathrm{p}<0.05$ level.

\section{Discussion}

Evaluating PER and CEA, it was noted that there was no significant difference between the experimental groups. PER values above 2.0 indicate protein of good quality, and values below 1.5 are associated with protein of low quality ${ }^{18}$. The values found in this experiment demonstrate that the feed with flaxseed, such as the control diet using only casein as protein source - a high biological value protein, provided adequate growth of animals. In a recent survey ${ }^{19}$, flaxseed was offered as a unique source protein to newly weaned female rats, resulting in extremely low PER values of 0.8 for FG and 2.3 for CG. This result indicates that flaxseed is a food protein with low quality and should not be supplied as the unique source of protein, since it interfered negatively on the animals' growth.

The total food and protein consumption were measured during the experiment in order to evaluate the food profile of the studied groups. There was a significant difference in consumption, lower in the FG than in CG. This can be justified by the seed composition, which is rich in soluble fiber. These fibers are viscous, hydrate easily, and have a great ability to form $\mathrm{gel}^{20}$. This leads to a decrease in the velocity of gastric emptying, and prolongation of satiety, resulting in reduced food intake ${ }^{21}$.

As for the effects caused by the oilseeds consumption on the weight gain of evaluated animals, these results corroborate those ones reported by other authors in studies with rodents ${ }^{22}$. In this study, the weight of offspring at birth was similar in both groups, however, at the end of 200 days of experiment, the animals that fed a rich diet in flaxseed weighed significantly lower than the 
other ones, showing that flaxseed can prevent excess weight gain even in healthy rats. These results are satisfactory, since they show that weight loss did not affect the animals' GI from FC, which was similar to the CG. Daleprane et al. ${ }^{23}$ supplemented weaned rats with $25 \%$ of flaxseed up to 180 days old and found lower body weight in animals that consumed the oilseed, although the growth rate has been similar to the CG. Weight loss is recommended as a strategy to reduce the risk of cardiovascular disease ${ }^{24}$.

Wu et al. ${ }^{25}$ reported that individuals consuming flaxseed have additional benefits on the adiposity and a greater tendency to lose weight. Abdominal obesity is asserted as a potential risk factor of $\mathrm{MS}^{26}$. Thus, the reversion of this fat accumulation is an important preventive measure against this disease onset. The mechanism by which flaxseed works in the reversal of abdominal obesity remains unclear, although evidences suggest that the abundance of polyunsaturated fatty acids in the diet can serve as a modulator for the body fat deposition ${ }^{25}$. Although no significant difference was found, the FG animals showed reduction of $16 \%$ in visceral fat mass. This result is similar to that found by Cardozo et al. ${ }^{27}$, who observed a trend of reduction in VFM in rats fed with flaxseed.

The consumption of flaxseed is linked directly to the improvement of plasma concentration of cholesterol and triglycerides, and, thus, a reduction of cardiovascular risk. Researches indicate beneficial results with different forms of the seed supplementation in nature under oil form or with different concentrations of SDG. In this experiment, it was observed that supplementation with integral flaxseed flour brought a significant improvement in lipid profile of the evaluated animals. Lower levels of total cholesterol and triglycerides were observed. Therefore, a beneficial effect of the seed used in this study on the serum lipids levels of animals was noted.

Fukumitsu et al. ${ }^{28}$ administered capsules of $20 \mathrm{mg}$ or 100 SDG to moderately hypercholesterolemic men, daily during 12 weeks, observing significant results in decrease of LDL/HDL ratio in those ones who ingested $100 \mathrm{mg}$ per day. Cardoso et al..$^{29}$ observed a decrease in plasmatic concentrations of TC and TG in mature rats that received seed flour components via breast milk during lactation. Another study ${ }^{30}$ examined the flaxseed oil offered with a high fat diet to male mice, verifying a reduction in the triglycerides levels and plasmatic cholesterol attributed to a lower ratio of omega 6: omega 3 . The studies mentioned above lead us to conclude that the flaxseed action is independent of dyslipidemia presence or the combined seed addition with a high fat diet, since in these studies the animals were healthy and consumed an isocaloric diet.
Another flaxseed component that may also have positive effects on lipid profile is the fiber, which is linked to a lower risk of CVD and diabetes. An increase of $10 \mathrm{~g}$ of total dietary fiber are associated with the decrease of $14 \%$ in risk of all coronary events and $27 \%$ in death risk from coronary heart disease ${ }^{31}$. The mechanisms of the fiber favorable effect on the lipid profile are not clear, but some studies suggest that the fibers could act positively on concentrations of serum cholesterol, because of their gelling properties ${ }^{32}$. The soluble fibers may exert their effects on cholesterol levels, increasing the excretion of biliary acids, thus reducing the gastrointestinal absorption of dietary cholesterol and altering the serum insulin levels ${ }^{33}$. In the colon, the fatty acids production of short chain by fermentation of soluble fiber also seems to contribute to decrease the synthesis of hepatic cholesterol $^{34}$

Some authors state that the serum concentrations levels of HDL-c are not substantially affected by the flaxseed diet ${ }^{35}$. Hypercholesterolemic individuals consumed $15 \mathrm{~g} /$ day of flaxseed in a period of three months and remained unchanged their HDL-c level ${ }^{36}$. Zhang et al. ${ }^{37}$ verified the effect of different SDG doses in hypercholesterolemic individuals for eight weeks and they noticed HDL-c decrease. These results showed an increase of $14 \%$ in HDL-c concentrations in the supplemented group, but it was not a significant difference. This increase, although slight, can reduce the progression propensity of CVD because an increase of $1 \mathrm{mg} /$ $\mathrm{dl}$ in $\mathrm{HDL}_{-}{ }_{\mathrm{C}}$ contents reduces in $4 \%$ the risk of heart disease. The low plasma concentrations of $\mathrm{HDL}_{-}{ }_{\mathrm{C}}$ are a predictive risk factor for coronary arterial disease ${ }^{38}$

The flaxseed was associated with lower blood glucose in the supplemented group with flaxseed diet (FG). This result may indicate that the seed improves insulin sensitivity, thereby increasing glucose uptake. In a recent study, it was found that the flaxseed has hypoglycemic effect on diabetic rats ${ }^{39}$, and SDG present in flaxseed provides better glycemic control in hypercholesterolemic humans ${ }^{37}$. One possible cause for this glycemia reduction is the presence of SDG, which reduces diabetes incidence through its antioxidant activity. Oxidative stress has been suggested as a possible cause for type 1 and type 2 diabetes $^{40}$.

One limitation of this study refers to the natural inability for direct extrapolation of the results from animal models to human beings. However, animal models are widely used to investigate the metabolic mechanisms

\section{Conclusions}

The risk factors for metabolic syndrome development 
and, therefore, for cardiovascular disease may be minimized by prolonged flaxseed consumption, since there was improvement in lipid and glycemic profile, and present anti-obesogenic action. Soon, flaxseed can be an affordable alternative in the adjuvant treatment of obesity and dyslipidemia.

\section{References}

1- Kanbak G, Akalin A, Dokumacioglo A, Ozcelik E, Bal C. Cardiovascular risk assessment in patients with type 2 diabetes mellitus and metabolic syndrome: role of biomarkers. Diabetes Metab Syndr Clin Res Rev. 2011;5(1):7-11.

2- Chillarón JJ, Goday A, Pedro-botetb J. Síndrome metabólico, diabetes mellitus tipo $1 \mathrm{y}$ resistencia a la insulina. Med Clin (Barc). 2008;130 (12):466-71.

3- Paschos P, Paletas K. Non alcoholic fatty liver disease and metabolic syndrome. Hippokratia. 2009;13(1):9-19.

4- $\quad$ Rana JS, Nieuwdorp M, Jukema JW, Kastelein JJP. Cardiovascular metabolic syndrome - an interplay of, obesity, inflammation, diabetes and coronary heart disease. Diabetes Obes Metab. 2007;9:218-32.

5- Blondeau B, Joly B, Perret C, Prince S, Bruneval P, LeliévrePérgorier M, Fassot C, Van Huyen JPD. Exposure in utero to maternal diabetes leads to glucose intolerance and high blood pressure with no major effects on lipid metabolism. Diabetes Metab. 2011;37(3):245-51.

6- Chen CC, Lin WY, Li CI, Liu CS, Li TC, Chen YT, Yang CW, Chang MP, Lin CC. The association of alcohol consumption with metabolic syndrome and its individual components: the Taichung community health study. Nutr Res. 2012;32:24-9.

7- Robinson LE, Buchholz AC, Mazurak VC. Inflammation, obesity, and fatty acid metabolism: influence of $n-3$ polyunsaturated fatty acids on factors contributing to metabolic syndrome. Appl Physiol Nutr Metab. 2007;32:1008-24.

8- Faintuch J, Horie LM, Barbeiro HV, Barbeiro DF, Soriano FG, Ishida RK, Cecconello I. Systemic inflamation in morbidly obese subjects: response to oral supplementation with alpha-linolenic acid. Obes Surg. 2007;17(3):341-7.

8- Covinqton MD. Omega-3 fatty acids. Am Fam Physician. 2004;70(1):133-40.

9- Rodriguez-Leyva D, Basset CMC, McCullough R, Pierce GN. The cardiovascular effects of flaxseed and its omega-3 fatty acid, alphalinolenic acid. Can J Cardiol. 2010;26(9):489-96.

10- Yuan JP, Li X, Xu SP, Wang J. H, Liu X. Hydrolysis kinetics of secoisolariciresinol diglucoside oligomers from flaxseed. J Agric Food Chem. 2008;56(21):10041-7.

11- Basset CM. Experimental and clinical research findings on the cardiovascular benefits of consuming flax seed. Appl Physiol Nutr Metab. 2009;34(5):965-74.

12- Marques AC, Hautrive TP, Moura GB, Callegaro MGK, Hecktheuer LHR. Efeito da linhaça (Linum usitatissimum L.) sob diferentes formas de preparo na resposta biológica em ratos. Rev Nutr. 2011;24(1):131-41.

12- Prasad K. Secoisolariciresinol diglucoside from flaxseed delays the development of type 2 diabetes in Zucker rat. J Lab Clin Med. 2001;138(1):32-9.

13- Paschos GK, Magkos F, Panagiotakos DB, Votteas V, Zampelas A. Dietary supplementation with flaxseed oil lowers blood pressure in dyslipidaemic patients. Eur J Clin Nutr. 2007;61(10):1201-6.

14- Cardozo LFMF, Soares LL, Brant LHC, Chagas MA, Pereira VA, Velarde LGC, Boaventura GT. Hematologic and immunological indicators are altered by chronic intake of flaxseed in Wistar rats.
Nutr Hosp. 2011;26(5):1091-6.

15- Reeves PG, Nielsen FH, Fahey Jr GC. AIN-93 purified diet of laboratory rodents: final report of the American Institute of Nutrition ad hoc Writing Committee on the Reformulation of the AIN-76A rodents diet. J Nutr. 1993;123(11):1939-51.

17- Angelis RC. Valor nutricional das proteínas: métodos e avaliação. Cad Nutr. 1995; $\quad$ 10:8-29.

18- Friedman M. Nutritional value of proteins from different food sources. A Review. J Agr Food Chem. 1996;44:6-29.

19- Soares LL, Pacheco JT, Brito CM, Troina AA, Boaventura GT, Guzmán-Silva MA. Avaliação dos efeitos da semente de linhaça quando utilizada como fonte de proteína nas fases de crescimento e manutenção em ratos. Rev Nutr. 2009;22:483- 91.

20- Retore M, Silva LP, Toledo GSP, Araújo IG, Eggers DP. Fontes de fibra de coprodutos agroindustriais protéicos para coelhos em crescimento. Ciênc Rural. 2010;40(4):963-9.

21- Easterby DG, Jones JK. Composition of linseed mucilage. Nature. 1950;165(4198):614.

22- Vijaimohan k, Mallika J, Sabitha KE, Subramaniyam S, Anandhan C, Devi SCS. Beneficial effects of alpha linolenic acid rich flaxseed oil on growth performance and hepatic cholesterol metabolism in high fat diet rats. Life Sci. 2006;79(5): 448-54.

23- Daleprane JB, Batista A, Pacheco JT, Silva AFE, Costa CA, Resende AC, Boaventura GT. Dietary flaxseed supplementation improves endothelial function in the mesenteric arterial bed. Food Res Int. 2010;43(8):2052-6.

24- Lillo JL. The endocannabinoid system as a novel approach for managing obesity. J Am Osteopath Assoc. 2007;107(4):12-20.

25- Wu H, Pan A, Yu Z, Qi Q, Lu L,Zhang G, Yu D, Zong G, Zhou Y, Chen X, Tang L, Feng Y, Zhou H, Chen X, Li H, DemarkWahnefried W, Hu FB, Lin X. Lifestyle counseling and supplementation with flaxseed or walnuts influence the management of metabolic syndrome. J Nutr. 2010;140(11):1937-42.

26- Robinson LE, Graham TE. Metabolic syndrome, a cardiovascular disease risk factor: role of adipocytokines and impact of diet and physical activity. Can J Appl Physiol. 2004;29(6):808-29.

27- Cardozo LFMF, Soares LL, Chagas MA, Boaventura GT. Maternal consumption of flaxseed during lactation affects weight and hemoglobin level of offspring in rats. $\quad \mathrm{J}$ Pediatr. $($ Rio J) 2010;86(2):126-30.

28- Fukumistsu S, Aida K, Shimizu H, Toyoda K. Flaxseed lignan lowers blood cholesterol and decreases liver disease risk factors in moderately hypercholesterolemic men. Nutr Res. 2010;30(7):4416.

29- Cardozo LFMF, Chagas MA, Soares LL, Troina AA, Boaventura GT. Exposure to flaxseed during lactation does not alter area or ephitelium height but changes lipid profile in rats. Nutr Hosp. 2010;25(2):250-5.

30- Riediger ND, Othman R, Fitz E, Pierce GN, Suh M, Moghadasian MH. Low n-6: n- 3 fatty acid ratio, with fish- or flaxseed oil, in a high fat diet improves plasma lipids and beneficially alters tissue fatty acid composition in mice. Eur J Nutr. 2008;47(3):153-60.

31- Pereira MA, O'Reilly E, Augustsson K, Fraser GE, Goldbourt U, Heitmann BL, Hallmans G, Knekt P, Liu S, Pietnen P, Spiegelman D, Stevens J, Virtamo J, Willett WC, Ascherio A. Dietary fiber and risk of coronary heart disease: a pooled analysis of cohort studies. Arch Intern Med. 2004;164(4):370-6.

32- Anderson JW. Dietary fibre, complex carbohydrate and coronary artery disease. Can J Cardiol. 1995;11:55-62.

33- Anderson JW, Hanna TJ. Impact of nondigestible carbohydrates on serum lipoproteins and risk for cardiovascular disease. J Nutr. 1999;129(7):1457-66. 
34- Schneeman BO. Gastrointestinal physiology and functions. Br J Nutr. 2002; 88(2):159-63.

35- Rosa DD, Sales RL, Moraes LF, Lourenço FC, Neves CA, Sabarense CM, Ribeiro SM, Peluzio MC. Flaxseed, olive and fish oil influence plasmatic lipids, lymphocyte migration and morphometry of the intestinal of Wistar rats. Acta Cir Bras. 2010;25(3):275-80.

36- Bierenbaum ML, Reichstein R, Watkins TR. Reducing atherogenic risk in hyperlipemic humans with flax seed supplementation: a preliminary report. J Am Coll Nutr. 1993;12(5):501-4.

37- Zhang W, Wang X, Liu Y, Tian T, Flickinger B, Empie MW, Sun SZ. Dietary flaxseed lignin extract lowers plasma cholesterol and glucose concentrations in hypercholesterolaemic subjects. Br J Nutr. 2008;99(6):1301-9.

38- Mora S, Cook N, Buring J, Ridker PM, Lee IM. Physical activity and reduced risk of cardiovascular events: potential mediating mechanisms. Circulation. 2007;116(19):2110-8.

39- Abuelgassim O. Effects of flax seeds and date palm leaves extracts on serum concentrations of glucose and lipids in alloxan diabetics rats. Pak J Biol Sci. 2010; 13(23):1141-5.

40- Prasad, K. Antioxidant activity of secoisolariciresinol diglucosidederived metabolites, secoisolariciresinol, enterodiol, and enterolactone. Int J Angiol. 2000; 9:220-5.

\section{Correspondence}

Lívia Hipólito Cardozo Brant

Rua Mário Santos Braga, 30/5 andar

24020-140 Niterói - RJ Brasil

Tel.: (55 21)2629-9860

liviahipolito@gmail.com

Received: March 12, 2012

Review: May 14, 2012

Accepted: June 11, 2012

Conflict of interest: none

Financial source: State of Rio de Janeiro Research Foundation (FAPERJ) and Co-ordination of improvement of higher academic staff (CAPES)

${ }^{1}$ Research performed at Laboratory of Experimental Nutrition (LabNE), Faculty of Nutrition of Niteroi, Fluminense Federal University (UFF), Niteroi-RJ, Brazil. 